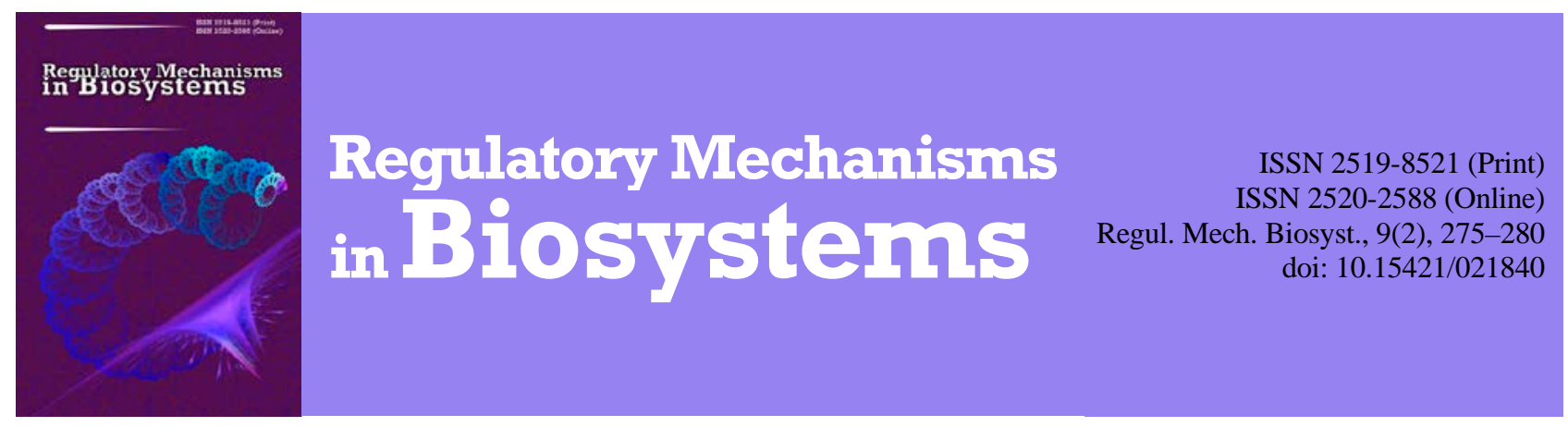

\title{
Isolation of Shiga toxin-producing strains of Escherichia coli from beef and swine carcasses and the characterization of their genes
}

\author{
O. M. Berhilevych*, V. V. Kasianchuk*, O. M. Deriabin**, M. D. Kukhtyn*** \\ *Sumy State University, Sumy, Ukraine \\ **State Scientific Control Institute of Biotechnology and Strains of Microorganisms, Kyiv, Ukraine \\ ***Ternopil Ivan Puluj National Technical University, Ternopil, Ukraine
}

\section{Article info}

Received 24.03.2018

Received in revised form 20.04.2018

Accepted 23.04.2018

Sumy State University,

Sanatorna st., 31 ,

Sumy, 40018, Ukraine.

Tel.: +38-067-903-89-96.

E-mail:

o.bergylevych@med.sumdu.edu.ua,

v.kasyanchuk@med.sumdu.edu.ua

State Scientific Control Institute

of Biotechnology and Strains

of Microorganisms,

Donetska st., 30,

Kyiv, 03151, Ukraine.

Tel.: +38-067-903-89-96.

E-mail:don.Imb@gmail.com

Ternopil Ivan Puluj National

Technical University,

Ruska st., 56,

Ternopil, 40061, Ukraine.

Tel.: +38-097-239-20-57.

E-mail: kuchtynnic@gmail.com
Berhilevych, O. M., Kasianchuk, V. V., Deriabin, O. M., \& Kukhtyn, M. D. (2018). Isolation of Shiga toxinproducing strains of Escherichia coli from beef and swine carcasses and the characterization of their genes. Regulatory Mechanisms in Biosystems, 9(2), 275-280. doi:10.15421/021840

Escherichia coli is part of the normal microflora of the intestinal tract of humans and warm-blooded animals, but its presence in raw material and food of animal origin is considered as fecal contamination and can be very dangerous for consumers. The determination of the number of $E$. coli in raw material and food is important because among them can be pathogenic strains. The most dangerous strains are considered enterohemorrhagic E. coli as a causative agent of severe bloody diarrhea and hemorrhagic uremic syndrome in humans through the production of Shiga-toxin, which is the main virulence factor, responsible for disease. The aim of this study was to identify the prevalence of Shiga toxinproducing strains of E. coli (STEC) from swabs of beef and swine carcass in slaughterhouses in Ukraine and characterize their genes, which are responsible for pathogenic properties. A total of 230 samples of swabs from beef (130) and swine (100) carcasses were obtained from 5 slaughterhouses in Ukraine between 2012 and 2015. Samples of swabs from carcasses were randomly selected at the final point of the process after the final washing of the carcass from the following areas: distal hind limb, abdomen (lateral and medial) from swine carcasses, brisket, flank and flank groin areas from beef carcasses. All samples were examined by culture-dependent method, after that each positive isolate of STEC was analyzed by multiplex PCR to detect the stx1, stx2, and eae genes. Out of 230 collected samples, seven (7.2\%) were contaminated with STEC. The highest prevalence of STEC was found in swabs from beef carcasses (8.1\%) in comparison to swabs from swine carcasses (5.7\%). The stx1 gene was the predominant gene detected in all STEC positive samples. The eae gene was found in one of the examined isolates from beef carcass. Three isolates from swabs of beef carcass carried both stx1 and stx2 genes, one isolate showed association between stx1 and eae genes, one isolate was positive for stx1 gene only. In swabs from swine carcasses (2 isolates) stx1 and stx2 genes were presented simultaneously. The results of this study suggested that fresh raw meat could be a potential vehicle for transmission of the Shiga toxin-producing strain of E. coli to humans. This is the first report of STEC prevalence in beef and swine carcasses in Ukraine and these data will be valuable for microbiological risk assessment and help the appropriate services to develop strategies to mitigate health risk.

Keywords: STEC; beef carcasses; swine carcasses; stx1; stx2; eae genes; multiples PCR

\section{Introduction}

Escherichia coli is a bacterium that normally inhabits the intestines of humans and warm-blooded animals. Most strains of E. coli are not harmful for them, but some strains are pathogenic causing gastrointestinal infections (Dhama et al., 2013; Ray \& Bhunia, 2014; Shuhong et al., 2015; Awadallah et al., 2016). Nowadays, more than 700 different serotypes of $E$. coli have been identified and divided into different serotypes according to their "O" (somatic or lipopolysaccharide) and " $\mathrm{H}$ " (flagellar) antigens. Pathogenic strains of $E$. coli are divided into six groups (enterotoxigenic, enteropathogenic, enteroinvasive, enterohemorrhagic, enteroaggregative and diffuse-adhering) based on their ability to produce toxins and to adhere and to invade intestinal epithelial cells (Rani et al., 2017; Vijayan et al., 2017). But the most pathogenic strains of E. coli of all known strains are enterohemorrhagic E. coli (EHEC). Serogroup O157:H7 of EHEC is the most frequently associated with serious food poisoning, which is accompanied by severe bloody diarrhea, hemorrhagic uremic syndrome (HUS) and can be lethal for humans.
Other serogroups (O26, O45, O103, O111, O121, O145) of EHEC are less common. One of the main characteristics of all of these serogroups is the production of Shiga-toxin (Stx), which is an important virulence factor, responsible for HUS. Because all enterohemorrhagic E. coli produce Shiga-toxin, they are also known as Shiga-toxigenic E. coli (STEC) or verotocxigenic E. coli (VTEC) because of their cytotoxic effect on Vero cells (Momtaz \& Jamshidi, 2013; Haugum et al., 2014, Ray \& Bhunia, 2014; Sudershan et al., 2014).

There are two types of Shiga-like toxins (Stx1 and Stx2) produced by STEC. Shiga-toxigenic E. coli can produce Stx1 only, Stx2 only, or both. The production of these toxins is regulated by bacteriophages which carry the stx genes and which lyosgenize strains of STEC. These bacteriophages are representative of the Stxencoding prophages. For E. coli O157:H7, the toxin genes are silent during lysogeny; however, if the phages are induced to enter the lytic cycle, phage and toxin production will occur. Induction to the lytic cycle can occur after exposure of the bacteria to DNA damaging agents, such as low iron conditions, UV light or mitomycin C, or to antibiotics (Puttalingamma et al., 2012; Rashid et al., 2013; Ray \& 
Bhunia, 2014). In addition to Shiga toxin production, another virulence factor expressed by STEC is intimin. Intimin is a membrane protein produced by all attaching enteric pathogens including STEC as an adherence factor for attachment to the intestinal epithelial cells. The eae gene codes produce this protein. STEC also have other adherence factors such as fimbriae, autotransporter, flagella, and EibG and Efa- 1 adhesin. The most virulent strains of STEC have all these genes. However, some strains of STEC are capable of having the gene that codes the first toxin (stx1), or the gene that codes the second toxin (stx2), or both genes (stx1and stx2) at the same time, or other combinations of three virulence genes (stx1, stx2 and eae) (Croxen et al., 2013; Awadallah et al., 2016; Soledad-Cadona et al., 2018).

Humans primarily become infected by Shiga toxin-producing $E$. coli through consumption of food of animal origin (Ju et al., 2012; Momtaz \& Jamshidi, 2013; Lozinak et al., 2016). Consumption of undercooked ground beef is the main source of infection as the meat can be easily contaminated with cattle feces during slaughter and butchering (Taye et al., 2013; Abdissa et al., 2017; Premarathne et al., 2017; Vijayan et al., 2017; Omoruyi et al., 2018). Although beef meat is considered as the main source of STEC for people, alimentary infections caused by STEC have also been described after consumption of swine meat (Troz-Williams et al., 2012; Tseng et al., 2014).

The disease caused by the toxin usually has very serious consequences for human health and can manifest by three different syndromes: hemorrhagic colitis (HC), hemolytic uremic syndrome (HUS), thrombotic thrombocytopenic purpura and which can even cause death (Majowicz et al., 2014; Smith et al., 2014; ECDC, 2016).

Due to the danger of STEC at the international level and to ensure food safety, it is officially recognized as a requirement to carry out research on the testing of these microorganisms in meat and meat products (Tafida et al., 2014; ECDC, 2016). It is possible to determine STEC by bacteriological methods that include the preenrichment of studied samples in broth with antibiotics, then isolation on agar typical colonies and then serotyping. To control STEC in each country, culture-dependent methods are different, but PCR - methods are the most rapid, sensitive and highly specific. Therefore, development and modifying a general technique of PCR - methods for detection of Shiga toxin-producing strain of $E$. coli are the focus of attention of scientists in different countries. Often, for rapid detection of the presence of several virulence factors of STEC in the samples, polymerase chain reaction (PCR) in multiplex version is used (Puttalingamma et al., 2012; Rantsiou et al., 2012; Haugum et al., 2014; Hara-Kudo et al., 2016).

It should be noted that at present in Ukraine rapid control techniques for STEC, including PCR, have not been developed yet, which is a deterrent to ensuring access of Ukrainian goods to foreign markets, especially the EU. In this regard, it is important to modify or adapt a general specific and rapid method of detection and identification Shiga toxin-producing strains of $E$. coli (STEC).

Therefore, the aim of this study was to identify the presence of the Shiga toxin-producing strains of $E$. coli on beef and swine carcasses in Ukraine and investigate their genetic characteristics. The following tasks were pursued in this study: (i) isolation of STEC from beef and swine carcasses (ii) modification of multiplex PCR method to detect the stx1, stx2, and eae genes (iii) to find out main the genetic characteristics of STEC from beef and pork carcasses.

\section{Materials and methods}

Samples collection. The work was performed in the Microbiology Laboratory of Center "Ecomedhim" in Sumy State University (Sumy, Ukraine), in the State Research Institute of Laboratory Diagnostics and Veterinary Expertise (Kyiv, Ukraine) and in the State Scientific Control Institute of Biotechnology and Strains of Microorganisms, (Kyiv, Ukraine). A total of 230 samples of swab from beef (130) and swine (100) carcasses were obtained from 5 slaughterhouses in Ukraine (Kyiv (3) and Sumy (2) regions) between 2012 and 2015. Swabs were collected with sterile tampons in sterile saline solution. Area selection of swabs was $100 \mathrm{~cm}^{2}$ from each carcass according to requirements ISO 17604. Samples of swabs from carcasses were selected randomly at the final point of the process after the final processing and washing of the carcass, from the following areas: distal hind limb, abdomen (lateral and medial) from swine carcasses, brisket, flank and flank groin areas from beef carcasses. After sampling, swabs were delivered to the laboratory at $4-5{ }^{\circ} \mathrm{C}$ in refrigerator-bags.

Methods of isolation and identification of E. coli from samples. Samples were examined for 2-12 hours. Swab samples were examinated by standard methods: serial dilutions of samples were plated on the surface of commercial medium "Compact Dry ${ }^{\mathrm{TM}}$ EC" for isolation of E. coli in Petri dishes (NISSUI pharma). It is a ready-touse chromogenic medium for performing $E$. coli and coliform counts. Petri dishes with isolates were incubated for $24 \mathrm{~h}$ at $37^{\circ} \mathrm{C}$. Interpretation of the results was performed by the following indicators: blue colonies were considered as E. coli.

Oligonucleotide primers. Alignment of nucleotide sequences and their homology analysis was performed by the module Clustalx software "Vector NTI" v.10.0.1 (Invitrogen) and Blast-analysis resource www.ncbi.nlm.him.gov (National Center for Biotechnology Information, USA). Primers for PCR multiplex variant were calculated by the software "Vector NTI" v.10.0.1 and synthesized in the "Lytech" (Russia). Lyophilized primers were diluted to a concentration of $100 \mathrm{pmol} / \mu \mathrm{l}$ "Ultra Pure Distilled Water" (Invitrogen, Cat. \# 10977-023, USA) and stored at $-20{ }^{\circ} \mathrm{C}$ until use. Specific oligonucleotide primers that were used for the detection of STEC are shown in Figure 1.
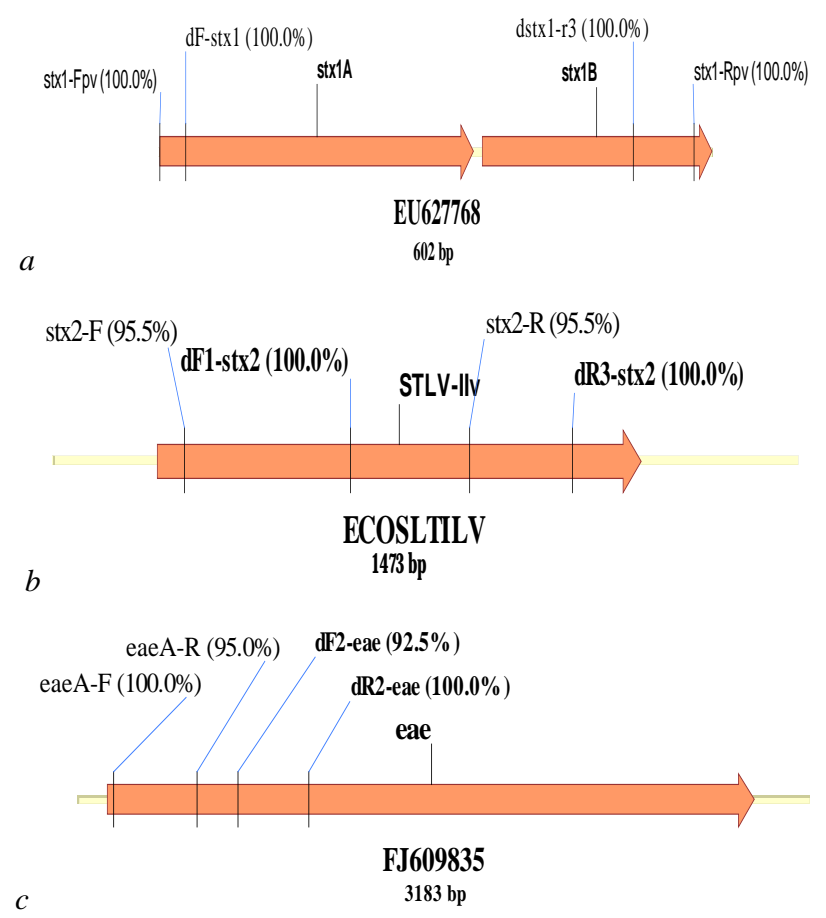

Fig. 1. Specific oligonucleotide primers specific to the toxin gene stx1 (a), stx2 (b) and intimin (eae) (c) that were used for the detection of Escherichia coli (STEC)

DNA isolation. DNA isolation was performed by three different methods: 1st - a colony of $E$. coli cultures was taken in a test tube with 0.5 microliters of sterile deionized water and was heated for 3 minutes at $100^{\circ} \mathrm{C}$, after that the tube was immediately transferred to ice; 2nd - selection using a commercial kit "DNA Sorb-B" (Amplysens, Russia); 3rd - using silica-modified ( $15 \mathrm{~nm}$ ) magnetic particles (synthesized and provided by N. Volkova, Institute of Physics and Biophysics NAS) with a concentration of $10 \mathrm{mg} \mathrm{m}^{-1}$ and saturation magnetization of $37 \mathrm{emu}\left(\mathrm{Am}^{2} / \mathrm{kg}\right)$, purification of bacterial DNA for spectrophotometric analysis was performed using a set of "Ultra Clean DNA Purification Kit" (Cat. \# 12500-100; Mobio, USA). The concentration and purity of drugs obtained DNA was measured on a spectrophotometer "NanoDrop 2000c" (USA). 
Polymerase chain reaction (PCR). PCR was performed in termocycles "Tertsyk" (DNA technology, Russia) and "T1" (Biometra, Germany). The reaction was carried out by "hot" start in a volume of $0.025 \mathrm{~cm}^{3}$. In order to minimize the formation of nonspecific dimers primer matrix and its amplification the method of preparation of the reaction mixture with the physical separation of PCR components was used.

To prepare the "lower" reaction mixture, nucleotydtryphosfate ( $2 \mathrm{mM}$ ) was mixed with appropriate primers in one tube at the rate of $0.025 \mathrm{~cm}^{3}$ each (final concentration from each primer 10-15 pmol/ sample). After mixing in a vortex, the mixture was dropped in prepared for PCR microtubes in volume $0.005 \mathrm{~cm}^{3}$ in each and on the top of it molten wax in volume $0.015 \mathrm{~cm}^{3}$ was added. After solidification of wax in the tube, the "upper" reaction mixture in volume 0.017 $\mathrm{cm}^{3}$ and 2 drops of mineral oil were added. The "upper" reaction mixture (1 sample calculation) consisted of $0.005 \mathrm{~cm}^{3}$ (x5) PCR buffer; $0.0025 \mathrm{~cm}^{3} 50 \mathrm{mM} \mathrm{MgSO}$; $0.009 \mathrm{~cm}^{3} \mathrm{H}_{2} \mathrm{O}$ MilliQ and $0.0005 \mathrm{~cm}^{3}$ Taq-polymerase ( 5 units $/ \mathrm{ml}$ ). Samples of bacterial DNA were placed under oil in the volume $0.003 \mathrm{~cm}^{3}$.

Thermal cycling parameters were as follows: $95^{\circ} \mathrm{C}$ for $3 \mathrm{~min}$, followed by 35 cycles of $94^{\circ} \mathrm{C}$ for $30 \mathrm{~s}, 65^{\circ} \mathrm{C}$ for $30 \mathrm{~s}, 72^{\circ} \mathrm{C}$ for $30 \mathrm{~s}$; and a terminal extension step of $72^{\circ} \mathrm{C}$ for $4 \mathrm{~min}$. Negative control was a non-pathogenic $E$. coli strain.

Electrophoretic analysis of PCR products. Analysis of amplification products was performed by separation of DNA fragments in a $1.5 \%(\mathrm{w} / \mathrm{v})$ agarose gel with containing $0.5 \mu \mathrm{g} / \mathrm{cm}^{3}$ ethidium bromides (Sigma, USA). Electrophoresis was performed at a constant voltage of $10 \mathrm{~V} / \mathrm{cm}$ to confirm the presence of the amplified DNA. Location of obtained DNA stripes and their registration was performed by using gel documentation system "Molecular Image Gel Doc XR+" (BioRad, USA).

\section{Results}

Modifying of PCR for identification of stx1, stx2 and intimin (eae) genes in isolated STEC. For the modifying of PCR for detection and identification of Shiga toxin-producing $E$. coli in beef and swine carcasses, first we performed research on the products received in PCR with oligonucleotide primers specific to the toxin gene stx1, stx2 and intimin (eae), which are pathogenicity markers for STEC. To design specific oligonucleotide primers, gene sequences in the databases GenBank, EMBL (European Molecular Biology Library), DDBJ (Japanese database nucleotide sequences) and PDB sequences were analyzed. As a basis, the following sequence had been selected: AB647443, AF022236, BA000007, ECOSTLII, AB647559, AB647430, AB647374, AB334567, AJ308552.1, AB647553.1, DQ523611.1, AB647374.1, H19BSLTA, KF771380.1, AB647493.1, AB647432.1, AB647437.1, AB647449.1, DQ523603.1, AB647365.1, EU700490.1, EF441598.1, EF441588.1.

As a basis, we have chosen a pair of oligonucleotide primers for the detection of E.coli O157:H7, which had been developed by Puttalingamma et al. (2012). We found that aforementioned primers contain palindromes and loops, and they influence the formation of numerous homo- and heterodimers that generally affect the specificity of the reaction. Simultaneous use of these primers in PCR multiplex option is not effective. The correct choice of oligonucleotide primers is very important because it determines the effectiveness and reproducibility of PCR.

The first task in the development of PCR was to improve the current method of detecting DNA of Shiga toxin-producing E. coli (STEC) by changing the composition of nucleotide sequences in primers for amplification of specific nucleic acid fragments. The developed primers could be used also in multiplex variant for detection of specific DNA fragments (stx1, stx2 and eae) of Shiga toxinproducing E. coli (STEC) in the samples.

Primer specificity was confirmed in test strains of heterological microorganisms Salmonella enterica, Listeria monocytogenes, Bacillus anthracis, Campylobacter jejuni, Pasterella multocida and Yersinia enterocolitica. To evaluate specificity and sensitivity of the reaction, optimal annealing temperature of the primers was determined (Fig. 2). To determine the sensitivity of the developed primers, 10 -fold serial dilutions of purified bacterial DNA were prepared. Concentration of purified DNA was determined with a spectrophotometer. Sensitivity for eae gene of 0145 strain was 0.220 and $0.021 \mathrm{ng}$ for genes stx1 and stx2 of O157 strain.

Results of isolation and identification of $E$. coli from samples. Among the 230 swabs, a total of 97 E. coli isolates (42.2\%) with typical cultural properties (blue colonies) was isolated by using commercial medium "Compact Dry" for isolation of E. coli in Petri dishes. The study was conducted on 62 isolates from the surfaces of beef and 35 isolates from swine carcasses (Table 1). More positive samples were detected from surfaces of beef (47.7\%) than from swine carcasses (35.0\%).

\section{Table 1}

Results of isolated $E$. coli from the examined samples $(\mathrm{n}=230)$

\begin{tabular}{lccc}
\hline \multicolumn{1}{c}{ Sample type } & $\begin{array}{c}\text { No. investigated } \\
\text { samples }\end{array}$ & $\begin{array}{c}\text { No. positive } \\
\text { samples }\end{array}$ & Percentages, \% \\
\hline Swabs from beef & 130 & 62 & 47.7 \\
Swabs from swine & 100 & 35 & 35.0 \\
\multicolumn{1}{c}{ Total } & 230 & 97 & 42.2 \\
\hline
\end{tabular}

These 97 isolates were further subjected to polymerase chain reaction (PCR). Multiplex PCR was used for detection of three target genes stx1, stx2 and eae in $97 \mathrm{E}$. coli isolates. Only $7 \mathrm{E}$. coli isolates (7.2\%) had at least one of 3 genes. Most of the isolates (6/85.7\%, $5 / 71.4 \%$ ) carried the stx1 or/and stx2 genes and only one isolate had the eae gene. Fragments of positive result of detection of PCR products of fragment gene of stx2 and gene eae are shown on Figure 2.

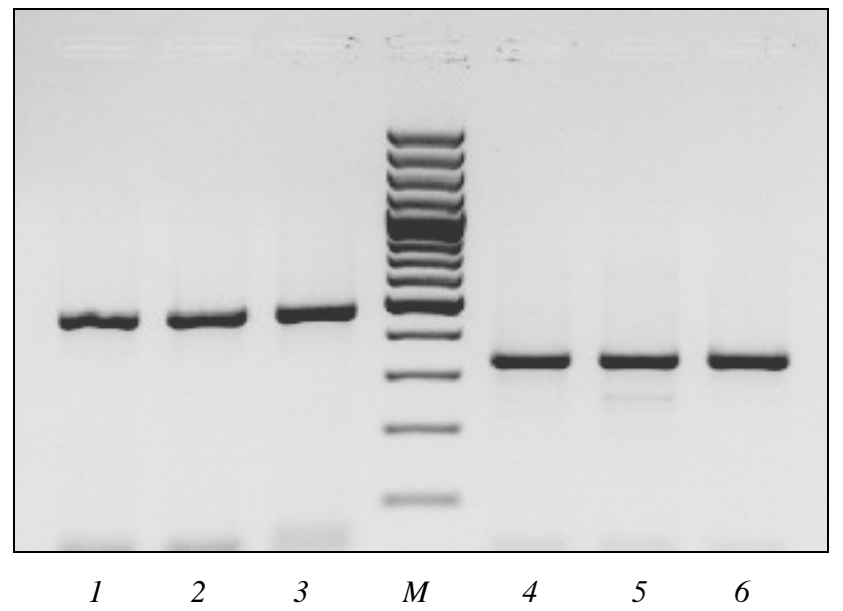

Fig. 2. Detection of PCR products of fragment gene of stx2 and gene eae after optimization of primer annealing temperature:

M - marker " 100 bp Plus DNA Ladder" (Thermo Scientific); gene stx2 $-1-63{ }^{\circ} \mathrm{C}, 2-64{ }^{\circ} \mathrm{C}, 3-65^{\circ} \mathrm{C}$; gene eae $-4-63{ }^{\circ} \mathrm{C}, 5-64{ }^{\circ} \mathrm{C}, 6-65^{\circ} \mathrm{C}$

Seven isolates (7.2\%) showed presence of stx1, stx2 and eae genes. The highest number of positive isolates was found in swabs from beef (5 isolates, 8.1\%) then the swabs from pork (2 isolates, 5.7\%). Among these 7 positive isolates: 6 isolates (4 isolates from beef carcasses and 2 isolates from swine carcasses) were confirmed for presence of the stx 1,5 isolates ( 3 isolates from beef carcasses and 2 isolates from swine carcasses) were confirmed for presence of the stx2 and only one isolate from beef carcass had a positive result for the eae gene (intimin) (Table 2).

Table 3 presents results of combinations of virulence genes (stx1, stx2, eae) in nine isolated strains of STEC. Three $(60 \%)$ from five isolates of STEC from Swabs from beef carcasses carried both stx1 and stx2 genes, one isolate (20\%) showed association between stx1 and eae genes, one isolate (20\%) had a positive result for stx1 genes only.

In swabs from swine carcasses stx1 and stx2 genes were present simultaneously in 2 isolates. It was established that no isolates of STEC showed positive results for all 3 target genes at same time. Stx1 and stx2 positive $E$. coli isolates were found to be predominant. 
All positive STEC isolates from swine carcasses were negative for virulence eae genes (Table 3).

\section{Table 2}

Results of incidence of virulence genes of STEC isolated from the examined samples $(n=97)$

\begin{tabular}{lcccc}
\hline \multirow{2}{*}{ Sample type } & No. investigated & \multicolumn{3}{c}{ Virulence genes } \\
\cline { 3 - 5 } & samples, (\%) & stx1 & stx2 & eae \\
\hline Swabs from beef carcasses & $5(8.1 \%)$ & 4 & 3 & 1 \\
Swabs from swine carcasses & $2(5.7 \%)$ & 2 & 2 & 0 \\
$\quad$ Total & $7(7.2 \%)$ & 6 & 5 & 1 \\
\hline
\end{tabular}

\section{Table 3}

The combinations of virulence genes of STEC (stx1, stx2, eae) in isolated strains $(n=7)$

\begin{tabular}{lccc}
\hline \multirow{2}{*}{$\begin{array}{c}\text { Combination } \\
\text { of virulence genes }\end{array}$} & \multirow{2}{*}{$\begin{array}{c}\text { No. investigated } \\
\text { samples }\end{array}$} & \begin{tabular}{c} 
No. positive samples \\
\cline { 3 - 4 } beef carcasses
\end{tabular} & $\begin{array}{c}\text { swabs from } \\
\text { swine carcasses }\end{array}$ \\
\hline stx1+ stx2+ eae & 0 & 0 & 0 \\
stx1+ stx2 & 5 & 3 & 2 \\
stx1+ eae & 1 & 1 & 0 \\
stx2+ eae & 0 & 0 & 0 \\
stx1 & 1 & 1 & 0 \\
stx2 & 0 & 0 & 0 \\
eae & 0 & 0 & 0 \\
\hline
\end{tabular}

\section{Discussion}

According to international epidemiological data, in all countries of the world, cases of foodborne illness among people are increasing. Therefore, within the framework of trade agreements between Ukraine and European countries, food and raw food of animal origin must be tested for safety before being shipped for export. One of the important criteria of current microbiological safety of raw meat and meat products (especially beef and pork) is the control of Shiga toxin-producing E. coli (STEC), because they are food-borne pathogens that are very serious threats to public health. STEC infection is associated with sporadic outbreaks of clinical diseases in humans, including severe hemorrhagic colitis, hemolytic uremic syndrome, thrombotic thrombocytopenic purpura,which can even cause death (Majowicz et al., 2014; Smith et al., 2014; Sudershan et al., 2014; ECDC, 2016).

$E$. coli are the most intensively studied microorganisms in the Enterobacteriaceae family, as well as in the overall bacterial community. Most strains of E. coli are harmless to human health, and some even are beneficial to their host by helping in absorption of nutrients and provide the normal intestinal microflora. However, several strains of $E$. coli can be human and/or animal pathogens. Among such dangerous strains are Shiga toxin-producing E. coli through the production of a cytotoxin known as the Shiga toxin (Stx), or verotoxin, that is encoded by two types of the stx gene (Stx1, Stx2) (Gould et al., 2013; Ray \& Bhunia, 2014; Bonardi et al., 2015; ECDC, 2016).

Shiga toxin-producing $E$. coli are enteropathogens which colonize the intestinal tracts of humans and animals. It is well-known that cattle and other ruminants are considered the primary reservoir of STEC (Jeon et al., 2013; Bonardi et al., 2015; Chui et al., 2015). The relationship between STEC of swine origin and human illness has yet to be determined, but some recent research data indicate that pigs also can be a source of STEC for humans through contaminated raw meat and products (ECDC, 2016; Bardasi et al., 2017). It is important to note that $E$. coli which colonize the gastrointestinal tract of cattle or pigs play an important role in STEC transmission to humans. (Ray \& Bhunia, 2014; Bonardi et al., 2015; Bardasi et al., 2017). During processing, beef or swine carcasses can be contaminated with STEC directly by feces or from contaminated hides, which threatens food safety as carcasses are further processed into meat products (Stromberg et al., 2018). The contaminated raw meat and meat products are identified as major sources of STEC strains for humans. Animal carcass contamination by $E$. coli occurs through dirty skin or feces from the intestinal tract during slaughter process at processing plants. But the detection of STEC from different products of animal origin is not only a reliable indicator of fecal contamination, but is also an indicator of poor hygiene and sanitary conditions during their production (Abdissa et al., 2016; Awadallah et al., 2016). Several scientific studies conducted in several countries have shown the prevalence of STEC strains in beef, swine and their products (Collins \& Boitumelo, 2014; Merwad et al., 2014; Tseng et al., 2014; ECDC, 2016; Beyi et al., 2017; Anu et al., 2018). These studies show that the incidence of isolation of STEC strains in beef, swine and their products vary in different regions of the world. But there is a lack of information about presence of STEC on beef and pork carcasses in Ukraine. Besides, despite the fact that fewer cases of swine-associated outbreaks of STEC infection have been reported than cattle-associated outbreaks, we assume that swine should not be overlooked as an important source of STEC infections in humans. The increase in STEC infection outbreaks worldwide among humans, associated with raw material of animal origin necessitates detailed study of the sources of these pathogens in order to develop control strategies.

Therefore, the main task of this study was to identify the presence of STEC on the surface of beef and pork carcasses from slaughterhouse in Ukraine. Also currently in Ukraine quick and effective methods for the control of STEC have not yet been developed. To modify multiplex PCR to identify of these microorganisms was the second task of our study. The last task was to detect the main genetic characteristics of STEC from beef and pork carcasses from slaughterhouses in Ukraine.

In our study, the incidence of isolation $E$. coli was $42.2 \%$ (97 positive isolates from 230 total isolates) in swabs from the surface of beef and swine carcasses. Out of 97 positive isolates only seven (7.2\%) were STEC. The higher prevalence of STEC in our study was found in swabs from beef (8.1\%) in comparison with results from pork swabs (3.0\%). Our result was higher than results reported by other researchers. In some reports STEC was detected from beef carcass at processing plants with a lower percentage: 0.5\%, 3.3\%, 4.5\% (Abdissa et al., 2017; Beyi et al., 2017; Anu et al., 2018). But, the largest number of Shiga-toxin producing strains of $E$. coli from samples of beef carcass was 30.0\% (Omoruyi et al., 2018). As other researchers have highlighted, pork carcasses sampled were positive in 4.1\% (Colello et al., 2016). Even though these results differ from each other, they are consistent with the assumption that beef and pork can be potential sources of STEC.

Often, for rapid detection of the presence one or more pathogenic factors of STEC in samples, polymerase chain reaction in multiplex version is used. Two types of Shiga toxin, stx1 and stx2 (encoded by stx1 and stx2 genes) are bacterial virulence STEC determinants that are associated with human disease and they are used as a markers for multiplex PCR (Puttalingamma et al., 2012; Rantsiou et al., 2012; Haugum et al., 2014; Hara-Kudo et al., 2016). STEC strains producing Stx2 are considered more virulent than Stx1 producers (Kavaliauskiene et al., 2017; Stromberg et al., 2018). Besides Shiga toxin production, another virulence factor of STEC is known. It is a membrane protein intimin, which causes attaching of STEC to the intestinal epithelial cells. The eae gene codes produce this protein. But, many experts contend that the most virulent strains of STEC have all these genes (stx1, stx2 and eae) or other combinations (Croxen et al., 2013; Awadallah et al., 2016; Soledad-Cadona et al., 2018).

In the basis of our task, the multiplex PCR for the detection of stx1, stx2, eae virulence genes out of 97 isolates which were identified as $E$. coli by culture-dependent method (specific blue colonies on commercial medium «Compact Dry» for isolation of $E$. coli) was developed and used. We synthesized six pairs of original oligonucleotide primers for this method. Their homology and position on the corresponding genes are shown in Figure 1.

In the present work, no samples showed positive results for all 3 target genes (stx1, stx2, eae) in one sample. Most of the STEC isolates carried the stx1 gene (6 from 7 isolates, $85.8 \%$ ) and stx 1 gene (5 from 7 isolates, $71.4 \%$ ). One isolate (14.3\%) carrying the eae gene was found from one examined sample of beef carcass only. The stx1 gene was the predominant gene detected in all STEC positive samples from beef and swine carcasses. Some authors have reported similar 
findings (Troz-Williams et al., 2012; Colello et al., 2016). But prevalence of STEC isolates carrying virulence genes stx1, stx2, intimin (eae) has been reported in lactating cows and in contact workers in dairy farms at Sharkia Province, Egypt (Merwad et al., 2014). Three isolates from swabs of beef carcass carried both stx 1 and stx2 genes, one isolate showed association between stx1 and eae genes, one isolate had positive result for stx1 genes only (Table 3). In contrast to this study, some results have shown that $E$. coli O157:H7 was absent in raw minced beef samples in Tripoli, Lebanon by using real-time PCR-based method (Omari et al., 2018).

Although a small number of research articles which implicate pork as a source of human infection have been reported, the results of these investigations consider that meat other than beef also can be potential vehicles of STEC transmission (Troz-Williams et al., 2012). It is important to note that in swabs from swine carcasses (2 isolates) stx1 and stx2 genes were presented. So, the results of our study indicate that swine can be a potential reservoir of STEC strains. The same researchers isolated from 465 not ready to eat pork samples 65 (14.0\%) stx-positive E. coli: the stx2 gene was detected more frequently (13.3\%) than the stx1 gene (1.3\%) and associations of genes in pork samples were next: stx1+eae $(0,4 \%)$, stx2+eae $(8.0 \%)$ and stx1+stx2+eae (0.7\%) (Bardasi et al., 2017). At slaughter houses in Argentina $4.1 \%$ of carcasses of swine were stx positive: $50 \%$ of isolates positive for stx2 and 16.0\% for stx1/stx2. (Colello et al., 2016).

\section{Conclusion}

This study is the first report on the presence of Shiga toxin-producing strains of $E$. coli (STEC) in beef and swine carcasses in Ukraine. The results indicate that fresh raw meat (beef and pork) could be potential vehicles for transmission of enterohemorraghic E. coli infections to humans since the highest prevalence these pathogenic microorganisms was found in swabs from beef carcasses and swine carcasses. These data will be valuable for microbiological risk assessment and help authorities to develop strategies to mitigate health risk.

This research did not receive any specific grant from funding agencies in the public, commercial, or not-for-profit sectors.

\section{References}

Abdissa, R., Haile, W., Fite, A. T., Beyi, A. F., Agga, G. E., Edao, B. M., Tadesse, F., Korsa, M. G., Beyene, T., Beyene, T. J., De Zutter, L., Cox, E., \& Goddeeris, B. M. (2017). Prevalence of Escherichia coli O157:H7 in beef cattle at slaughter and beef carcasses at retail shops in Ethiopia. MC Infectious Diseases, 17(1), 277-283.

Anu, P. J., Latha, C., Vinodkumar, K., Vinod, V. K., \& Sathu, T. (2018). An important approach for control of Enterohaemorrhagic Escherichia coli by identification of contaminating sources in beef production line. International Journal of Current Microbiology and Applied Sciences, 7(1), 1921-1929.

Awadallah, M. A., Ahmed, H. A., Merwad, A. M., \& Selim, M. A. (2016) Occurrence, genotyping, shiga toxin genes and associated risk factors of E. coli isolated from dairy farms, handlers and milk consumers. The Veterinary Journal, 217, 83-88.

Bardasi, L., Taddei, R., Fiocchi, I., Pelliconi, M. F., Ramini, M., Toschi, E., \& Merialdi, G. (2017). Shiga toxin-producing Escherichia coli in slaughtered pigs and pork products. Italian Journal of Food Safety, 6, 6579-6584.

Beyi, A. F., Fite, A. T., Tora, E., Tafese, A., Genu, T., Kaba, T., Beyene, T. J., Beyene, T., Korsa, M. G., Tadesse, F., Zutter, L., Goddeeris, B. M., \& Cox, E. (2017). Prevalence and antimicrobial susceptibility of Escherichia coli $\mathrm{O} 157$ in beef at butcher shops and restaurants in central Ethiopia, BMC Microbiology, 17, 49-55.

Bonardi, S., Alpigiani, I., Tozzoli, R., Vismarra, A., Zecca, V., Greppi, C., Bacci, C., Bruini, I., \& Brindani, F. (2015). Shiga toxin-producing Escherichia coli O157, O26 and O111 in cattle faeces and hides in Italy, Veterinary Record Open, 2, 1-10.

Hara-Kudo, Y., Konishi, N., Ohtsuka, K., Iwabuchi, K., Kikuchi, R., Isobe, J., Yamazaki, T., Suzuki, F., Nagai, Y., Yamada, H. and Tanouchi, A. (2016). An interlaboratory study on efficient detection of Shiga toxin-producing Escherichia coli O26, O103, O111, O121, O145, and O157 in food using real-time PCR assay and chromogenic agar. International Journal of Food Microbiology, 230, 81-88.
Haugum, K., Brandal, L. T., Lindstedt, B. A., Wester, A. L., Bergh, K., \& Afseta, J. E. (2014). PCR-based detection and molecular characterization of Shiga toxin producing Escherichia coli strains in a routine microbiology laboratory over 16 years. Journal of Clinical Microbiology, 52(9), 3156-3163.

Jeon, S. J., Elzo, M., Dilorenzo, N., Lamb, G. C., \& Jeong, K. C. (2013). Evaluation of animal genetic and physiological factors that affect the prevalence of Escherichia coli O157 in cattle. PLoS One, 8(2), 1-9.

Ju, W., Shen, J., Li, Y., Toro, M. A., Zhao, S., Ayers, S., Najjar, M. B., \& Meng, J. (2012). Non-O157 Shiga toxin-producing Escherichia coli in retail ground beef and pork in the Washington D.C. area. Food Microbiology, 32, 371-377.

Kavaliauskiene, S., Dyve Lingelem, A. B., Skotland, T., \& Sandvig, K. (2017). Protection against Shiga toxins. Toxins (Basel), 9(2), e44.

Lozinak, K. A., Jani, N., Gangiredla, J., Patel, I., Elkins, C. A., Hu, Z., Kassim, P. A., Myers, R. A., \& Laksanalamai, P. (2016). Investigation of potential shiga toxin producing Escherichia coli (STEC) associated with a local foodborne outbreak using multidisciplinary approaches. Food Science, 5(3), 163-168.

Majowicz, S. E., Scallan, E., Jones-Bitton, A., Sargeant, J. M., Stapleton J., Angulo, F. J., Yeung, D. H., \& Kirk, M. D. (2014). Global incidence of human Shiga toxin-producing Escherichia coli infections and deaths: A systematic review and knowledge synthesis. Foodborne Pathogens and Disease, 11, 447-455.

Merwad, A., Gharieb, R., \& Saber, T. (2014). Occurrence of shiga toxin-producing Escherichia coli in lactating cows and in contact workers in Egypt: Serotypes, virulencegenes and zoonotic significance. Life Science Journal, 11(5), 563-571.

Microbiology of the food chain. Carcass sampling for microbiological analysis (2015). European Centre for Disease Prevention and Control. Escherichia coli factsheet Stockholm: ECDC. ISO 17604:2015.

Momtaz, H., \& Jamshidi, A.(2013). Shiga toxin-producing Escherichia coli isolated from chicken meat in Iran: Serogroups, virulence factors, and antimicrobial resistance properties. Poultry Science, 92, 1305-1313.

Omari, K. E., Kassaa, I. A., Kara-Ali, H., Dabboussi, F., \& Hamze, M. (2018). Prevalence of E. coli O157:H7 in raw minced beef at slaughterhouses in Tripoli, Lebanon. Virology and Immunology Journal, 2(4), 2-4.

Omoruyi, I. M., Uwadiae, E., Mulade, G., \& Omoruku, E. (2018). Shiga toxin producing strains of Escherichia coli (STEC) associated with beef products and its potential pathogenic effect. Microbiology Research Journal International, 23(1), 1-7.

Premarathne, J. M. K. J. K., New, C. Y., Ubong, A., Nakaguchi, Y., Nishibuchi, M., \& Son, R. (2017). Risk of Escherichia coli O157:H7 infection linked to the consumption of beef. Food Research, 1(3), 67-76.

Puttalingamma, V., Shylaja, R., Batra, H. V., \& Bawa, A. S. (2012). A novel multiplex PCR system for the detection of virulence associated genes of E. coli O157:H7 from food system. Recent Research in Science and Technology, 4(5), 36-40.

Rani, S., Singh, Y., Gulati, B. R., \& Khurana, S. K. (2017). Occurrence of enterohaemorrhagic Escherichia coli in buffalo meat. Journal of Experimental Biology and Agricultural Sciences, 5(2), 208-214.

Rantsiou, K., Alessandria, V., \& Cocolin, L. (2012). Prevalence of Shiga toxinproducing Escherichia coli in food products of animal origin as determined by molecular methods. International Journal of Food Microbiology, 154, 37-43.

Rashid, M., Kotwal, S. K., Malik, M. A., \& Singh, M. (2013). Prevalence, genetic profile of virulence determinants and multidrug resistance of Escherichia coli isolates from foods of animal origin. Veterinary World, 6, 139-142.

Ray, B., \& Bhunia, A. (2014). Fundamental food microbiology. CRC Rress, Taylor \& Francis Group, New York.

Shuhong, Z., Xuemei, Z., Qingping, W., Jumei, Z., Xiaoke, X., \& Haigang, L., (2015). Prevalence and characterization of Escherichia coli O157 and O157:H7 in retail fresh raw meat in South China. Annals of Microbiology, 65, 1993-1999.

Smith, J. L., Fratamico, P. M., \& Gunther, N. W. T. (2014). Shiga toxin-producing Escherichia coli. Advances in Applied Microbiology, 86, 145-197.

Soledad-Cadona, J., Bustamante, A. V., González, J., \& Mariel-Sanso, A. (2018). Pathogenicity islands distribution in non-O157 Shiga toxin-producing Escherichia coli (STEC). Genes, 9, 81-99.

Stromberg, Z. R., Redweik, G. A. J., \& Mellata, M. (2018). Detection, prevalence, and pathogenicity of Non-O157 shiga toxin-producing Escherichia coli from cattle hides and carcasses. Foodborne Pathogens and Disease, 15(3), 119-131.

Sudershan, R. V., Naveenkumar, R., Kashinath, L., Bhaskar, V., Polasa, K. (2014). Foodborne infections and intoxications in Hyderabad India. Epidemiolody Research International, 10, 1-5.

Tafida, S. Y., Kwaga, J. K. P., Bello, M., Kabir, J., Umoh, V. J., Yakubu, S. E., \& Nok, A. J. (2014). Occurrence of Escherichia coli 0157 in retailed-beef and related meat products in Zaria, Nigeria. Food and Nutrition Sciences, 5, 481-487. 
Taye, M., Berhanu, T., Berhanu, Y., Tamiru, F., \& Terefe, D. (2013). Study on carcass contaminating Escherichia coli in apparently healthy slaughtered cattle in Haramaya University Slaughter House with special emphasis on Escherichia coli O157:H7. Journal of Veterinary Science and Technology, 4, 132.

Troz-Williams, L. A., Mercer, N. J., Walters, L. M., Maki, A. M., \& Johnson, R. P. (2012). Pork implicated in a Shiga toxin-producing Escherichia col O157:H7 outbreak in Ontario, Canada. Canadian Journal of Public Health, 103, 322-326.
Tseng, M., Fratamico, P. M., Bagi, L., Manzinger, D., \& Funk, J. A. (2014). Shiga toxin-producing E. coli (STEC) in swine: Prevalence over the finishing period and characteristics of the STEC isolates. Epidemiology and Infection, 8, 1-10.

Vijayan, C., Ajaykumar, V. J., Bhattacharya, A., \& Bhanurekka, V. (2017). Detection of enterohaemorrhagic $E$. coli O157: $\mathrm{H} 7$ from beef and chevon sold in and around Puducherry. Journal of Entomology and Zoology Studies, 5(6), 1395-1403. 